\title{
MENUMBUHKAN KARAKTER BAIK MELALUI PERANAN GURU DI SEKOLAH
}

\author{
Yoyo Zakaria Ansori, Sigit Vebrianto Susilo, Tsaniya Farhatina \\ Universitas Majalengka \\ Email al.anshory0928@gmail.com
}

\begin{abstract}
ABSTRAK
Sekolah sebagai suatu organisasi dituntut untuk menjalankan tujuannya yaitu membentuk siswa berkarakter. Tujuan tersebut akan tercapai melalui peran guru. Peranan guru sebagai pendidik adalah membentuk sikap individu sebagai pembelajar yang bertanggung jawab dan mampu mengamalkan ilmunya demi kebaikan diri dan sesama manusia. Pendidikan merupakan penanaman nilai yang diyakini masyarakat tidak sebatas pengetahuan tetapi perlu menyentuh sikap dan perilaku peserta didik. Pengembangan pendidikan berangkat dari nilai individu dan diwujudkan secara holistik, sehingga peserta didik menjadi manusia yang utuh, yakni berkarakter positif, berbudi pekerti yang luhur dan berakhlak mulia. Untuk mewujudkannya maka peran guru dalam membangun karakter siswa yakni sebagai konservator (pemelihara), sebagai transmitter (penerus) sistem nilai, sebagai transformator (penerjemah) sistem nilai, dan sebagai organisator (penyelenggara) terciptanya proses pendidikan.
\end{abstract}

Kata Kunci: Karakter Baik, Peran Guru 


\section{Pendahuluan}

Secara historis pendidikan karakter merupakan misi utama para Rasul, Islam hadir sebagai gerakan untuk menyempurnakan karakter. Sejak abad ke7 secara tegas Rasulullah Muhammad saw. Menyatakan bahwa tugas utama dirinya adalah untuk menyempurnakan akhlak (karakter). Manifesto kerasulan Muhammad ini, mengindikasikan bahwa pembentukan karakter merupakan kebutuhan utama bagi tumbuhnya cara beragama yang dapat menciptakan peradaban. (Q-Anees dan Hambali, 2008:100).

Sementara itu landasan pendidikan karakter di sekolah terangkum pada Undang-Undang No. 20 tahun 2003 tentang Sistem Pendidikan Nasional (Sisdiknas) bab II pasal 3:

Pendidikan nasional berfungsi mengembangkan kemampuan dan membentuk watak serta peradaban bangsa yang bermartabat dalam rangka mencerdaskan kehidupan bangsa, bertujuan untuk berkembangnya potensi peserta didik agar menjadi manusia yang beriman dan bertakwa kepada Tuhan Yang Maha Esa, berakhlak mulia, sehat, berilmu, cakap, kreatif, mandiri, dan menjadi warga negara yang demokratis serta bertanggungjawab

Tujuan pendidikan nasional tersebut memberikan arah bahwa output lembaga sekolah harus memiliki moralitas yang baik. Beberapa penelitian telah membuktikan akan pentingnya pendidikan karakter:

Research has shown that many schools with successful character education programs have experienced fewer disciplinary referrals for misbehavior, improved school attendance, fewer student drop-outs, and higher performance scores on standardized achievement tests (Wynne \& Ryan, 1997 dalam Najah

\section{A. R. Ghamrawi, Norma Ghamrawi,} dan Tarek Shal, 2015 hal.130).

Hasil penelitian tersebut menunjukkan bahwa sekolah yang melaksanakan program pendidikan karakter telah sukses menumbuhkan perilaku disiplin, meningkatkan kehadiran siswa di sekolah, sedikit siswa yang dropout, mengurangi kekerasan, intimidasi dan meningkatkan prestasi siswa melalui kegiatan belajar di sekolah.

Peran guru dalam mewujudkan hal tersebut di atas dipandang penting karena guru merupakan teladan sekaligus juga sebagai garda terdepan dalam pembinaan karakter siswa di sekolah. Namun dewasa ini, masih ada sebagaian guru yang memandang tidak utuh proses pendidikan. Pendidikan "cenderung menitikberatkan pada hapalan dan mendapatkan nilai bagus mengabaikan pengembangan sikap dan karakter warga negara (Djahiri:1996:2). Senada dengan itu, menurut Mulyana (2011 hal. 115) pendidikan diarahkan pada peningkatan kemampuan otak kiri. Sebaliknya kemampuan otak kanan kurang ditumbuhkembangkan. Bahkan dapat dikatakan tidak pernah dikembangkan secara sistematis. Dengan kata lain, jika meminjam istilah Paulo Preire (2011 hal. 116) praktik pendidikan formal saat ini dapat dikatakan memenuhi kriteria banking system of education yang tidak dapat membebaskan peserta didik dari ketertindasan.

Pendidikan seperti itu akan menghasilkan siswa yang pinter otaknya tetapi tumpul hatinya, mengakibatkan pelanggaran moral di lingkungan sekolah menjadi bagian dari perilaku sehari-hari, seperti perkelahian antar pelajar, minuman keras dan narkotika, hingga pergaulan bebas. Pelanggaran moral siswa di sekolah seperti terangkum di bawah ini: 


\begin{tabular}{llc}
\hline No & \multicolumn{1}{c}{ Kasus } & $\%$ \\
\hline 1 & \multicolumn{1}{c}{$\begin{array}{l}\text { Siswa pernah mengalami } \\
\text { kekerasan di sekolah }\end{array}$} & $84 \%$ \\
\hline 2 & $\begin{array}{l}\text { Siswa mengalami } \\
\text { kekerasan di sekolah }\end{array}$ & $75 \%$ \\
\hline 3 & $\begin{array}{l}\text { Siswa laki-laki } \\
\text { menyebutkan bahwa }\end{array}$ & $45 \%$ \\
& $\begin{array}{l}\text { guru atau petugas } \\
\text { sekolah merupakan }\end{array}$ \\
& pelaku kekerasan \\
\hline 4 & $\begin{array}{l}\text { Siswa perempuan } \\
\text { menyebutkan bahwa }\end{array}$ \\
& $\begin{array}{l}\text { guru atau petugas } \\
\text { sekolah merupakan } \\
\text { pelaku kekerasan }\end{array}$ \\
\hline 5 & $\begin{array}{l}\text { Siswa usia 13 - 15 tahun } \\
\text { melaporkan pernah }\end{array}$ \\
& $\begin{array}{l}\text { mengalami kekerasan } \\
\text { fisik teman sebaya }\end{array}$ \\
\hline 6 & $\begin{array}{l}\text { Siswa melaporkan } \\
\text { mengalami perundungan } \\
\text { (bullying) di sekolah. }\end{array}$ \\
\hline
\end{tabular}

Sumber Hakam (2015)

Semua fenomena tersebut mengindikasikan bahwa belum berhasilnya pendidikan moral dan pendidikan karakter secara memuaskan di sekolah. Oleh karena itu, sekolah sebagai suatu organisasi dituntut untuk mengeliminir kejadian-kejadian di atas. Hal tersebut tersebut dapat tercapai apabila guru memandang utuh hakikat pendidikan. Menurut Hakam (2016) pendidikan pada hakikatnya upaya menanamkan nilai pada individu dan mengembangkan potensi kebernilaian individu atau kelompok ke arah kematangan. Sementara menurut Nurihsan (2016 hal. 11) pendidikan diartikan sebagai upaya mengembangkan mutu pribadi dan membangun karakter bangsa yang dilandasi nilai-nilai agama, filsafat, psikologi, sosial budaya, ilmu pengetahuan dan teknologi.

Dalam membina karakter siswa di sekolah guru merupakan garda terdepan dan memiliki peran yang sangat sentral. Makmun (2005 hal. 23) menjelaskan secara luas peran guru dalam membangun karakter siswa yakni sebagai konservator (pemelihara), sebagai transmitter (penerus) sistem nilai, sebagai transformator (penerjemah) sistem nilai, dan sebagai organisator (penyelenggara) terciptanya proses pendidikan. Melihat uraian tersebut, maka dengan jelas peran guru sangat penting dalam membina karakter siswa, sehingga peneliti tertarik untuk mengadakan penelitian dengan judul Peran Guru dalam Pembinaan Karakter Siswa.

\section{Metode Penelitian}

Metode yang digunakan dalam penelitian ini adalah metode penelitian deskriptif. Kutha menjelaskan metode deskriptif adalah analisis yang dilakukan dengan cara mendeskripsikan fakta-fakta yang kemudian disusul dengan analisis, tidak semata-mata menguraikan, melainkan juga memberikan pemahaman dan penjelasan secukupnya (2010:30). Adapun teknik pengumpulan data dalam penelitian ini dengan menggunakan studi pustaka (library research) dimana peneliti mengumpulkan data dengan cara membaca, mempelajari, dan menganalisis jurnal-jurnal, buku, artikel dari peneliti terdahulu yang ada hubungannya dengan obyek penelitian.

Studi Kepustakaan Menurut Sugiyono (2016:291), berkaitan dengan kajian teoritis dan referensi lain yang berkaitan dengan nilai, budaya dan norma yang berkembang pada situasi sosial yang diteliti, selain itu studi kepustakaan sangat penting dalam melakukan penelitian, hal ini dikarenakan penelitian tidak akan lepas dari literatur-literatur ilmiah. Data diperoleh dari data yang relevan terhadap permasalahan yang akan diteliti dengan melakukan studi pustaka lainnya seperti buku, jurnal, artikel, peneliti terdahulu

\section{Hasil Penelitian}

Ditilik dari tugas utamanya, peranan guru sebagai pendidik adalah membentuk 
sikap individu sebagai pembelajar yang bertanggung jawab dan mampu mengamalkan ilmunya demi kebaikan diri dan sesama. Untuk itu, tanggung jawab moral guru sebagai pendidik dan pengajar adalah membangun dasar ilmu pengetahuan, menumbuhkan keterampilan dan kemampuan berpikir kritis sehingga peserta didik mampu memahami persoalan hidup dan menyelesaikan persoalan kehidupan dengan ilmu yang dimilikinya. Melahirkan seorang pembelajar sepanjang hayat, itulah tugas utama seoarang pendidik.

Selain sebagai seorang pendidik, guru juga adalah jabatan professional yang melayani publik. Dalam melaksanakan tugas-tugas tersebut, seoarang guru harus tetap berpijak pada prinsip-prinsip moral yang menjadi tanggung jawab profesinya. Prinsip moral pertama yang perlu diingat oleh guru adalah bahwa apa yang dilakukannya, hendaknya untuk kebaikan siswa yang menjadi motivasi utama. Ini adalah salah satu prinsip moral dasar yang perlu diingat oleh guru yaitu melakukan kebaikan (doing the good), hal tersebut selaras dengan pendapatnya Lickona The characters...very consistent with good knowledge, passion is good, and doing good (1991 hal. 51). Artinya, perspektif moral guru dalam setiap tindakan, perkataan, dan perbuatannya adalah selalu mengarah kepada hasil-hasil yang membawa pada kebaikan. Oleh sebab itu dalam melaksanakan profesinya seorang guru harus memiliki standar moral dan etika profesi, tanpa itu lembaga pendidikan hanya akan diisi oleh orangorang yang bernafsu memuaskan kepentingan diri dan kelompoknya, bahkan bisa jadi menindas mereka yang tidak memiliki kekuasaan. "Tanpa etika profesi, kebebasan dan individu tidak dihargai, tanpa etika profesi, tidak akan ada pendidikan karakter"(Kesuma, 2015 hal. 153)
Prinsip moral kedua tidak merusak (doing no narm). Prinsip ini mengatakan bahwa kalau seorang guru belum bisa membuat sesuatu atau melakukan sesuatu yang labih baik, minimal ia tidak melakukan sesuatu yang merusak. Jadi, lebih baik mempertahankan apa yang sudah ada meskipun belum mendatangkan kebaikan, daripada melakukan hal-hal yang justeru malah mundur, merugikan atau merusak. Bila hal itu dilakukan oleh guru dan itu berakibat adanya kerusakan dalam diri siswa, kiranya tindakan, sikap, dan keputusan itu itu dilakukan karena bertentangan dengan prinsip nilai moral. Bila kita belum bisa melakukan sesuatu yang lebih baik, minimal janganlah kita melakukan sesuatu yang merusak.

Prinsip moral yang ketiga adalah penghargaan atas kemartabatan individu. Prinsip ini secara sederhana mengatakan bahwa guru sebagai seorang individu tidak boleh memanfaatkan murid atau orang lain sebagai objek bagi pemenuhan tujuan hidupnya. Dengan kata lain, kita tidak boleh memanfaatkan orang lain sebagai objek demi kepentingan diri sendiri. Sebagai guru, kita perlu menghargai individu itu sebagai sosok yang berharga dan bermartabat sehingga kita tidak boleh menjadikan orang lain sebagai objek. Memanipulasi orang lain demi kepentingan egoisme, dianggap sebagai sesuatu yang melanggar prinsip moral.

Sedangkan menurut Hakam (2013) untuk membangun individu sebagai sosok yang berharga dan bermartabat dapat dilaksanakan melalui empat hal. Pertama melalui keteladanan, artinya pada tahap awal siapapun harus belajar moral dan karakter melalui percontohan, dan dalam mencontoh diperlukan figur yang patut dicontoh, guru dituntut untuk menjadi panutan dan pribadi yang menampilkan nilai-nilai moral. Hal tersebut selaras dengan pendapatnya Revell and Arthur dalam Agboola dan Tsai (2012 hal. 166) 
The attitudes of student teachers toward moral education also play an imperative role in the process of implementation of moral education. That is, it should be part of the curriculum of teacher education.

Bahwa Sikap guru pada siswa menuju pendidikan moral memainkan peran penting dalam proses pelaksanaan pendidikan moral. Artinya, itu harus menjadi bagian dari kehidupan pendidikan guru.

kedua melalui pembiasaan. Perilaku baik perlu dibiasakan, bukan merupakan pilihan, tetapi menjadi keharusan. Pembiasaan perbuatan baik harus terus menerus bukan situasional. Terjadinya inkonsistensi perbuatan moral, sering mendorong anak untuk memilih tindakan immoral. Untuk itulah diperlukan adanya suasana yang kondusif di sekolah agar nilai moral dapat teraplikasikan dalam setiap tindakannya. Ketiga, melalui sosialisasi, yaitu menyampaikan nilai moral pada publik, baik melalui pengajaran, ceramah, khotbah, slogan, simbolisasi, berita, yang sifatnya selalu mengingatkan individu agar berbuat kebajikan. Keempat membangun motivasi moral, yaitu menghadapkan individu atau kelompok pada sejumlah pilihan (baik perilaku maupun pertimbangan) yang sifatnya dilematis. Dilema moral seperti ini untuk mengokohkan prinsif moral yang telah ada pada diri individu, sehingga pada situasi apapun orang akan tetap konsisten berlaku bijak, tanpa memperhatikan situasi dan kondisi serta resiko yang diterimanya. Pribadi yang berprinsip inilah yang diupayakan melalui Pendidikan Karakter, sehingga moralitas dan akhlakul karimah menjadi watak seseorang.

Keempat langkah pendidikan karakter tersebut harus terus menerus dilakukan oleh guru, terutama langkah pertama dan kedua harusnya menjadi bagian integral dari kepribadian para pendidik, peran ketiga dan keempat sebaiknya dilakukan melalui metode pendidikan nilai dan moral yang bervariasi, sehingga peserta didik dilatih mengklarifikasi nilai, dibiasakan menghadapi dilema moral, menggunakan pertimbangan moral yang semakin matang, mampu menganalisis nilai sosial.

Melihat uraian tersebut, maka pembinaan dan pengembangan pendidikan karakter diyakini perlu dan sangat penting dilakukan sekolah untuk menjadi pijakan dalam penyelenggaraan pendidikan. Tujuan pendidikan karakter pada dasarnya adalah mendorong lahirnya anak-anak yang baik dan cerdas. Hal tersebut selaras dengan pendapatnya Lickona (Kristyn Marie Harms, 2004, hal. 23) the two goals of education were to help people become smart and to help them become good pada dasarnya pendidikan karakter memiliki dua tujuan yaitu membimbing para generasi muda untuk menjadi cerdas dan berperilaku baik. Karakter guru yang baik merupakan faktor yang sangat penting dalam pembinaan pendidikan karakter siswa sehingga akan menumbuhkan dan berkembangnya karakter yang baik serta mendorong peserta didik tumbuh dengan kapasitas dan komitmennya untuk melakukan berbagai hal yang terbaik dan melakukan segalanya dengan benar dan memiliki tujuan hidup.

Guru memiliki wewenang yang luas sesuai dengan ketentuan dan peraturan yang ada. Melalui kebijakannya, guru dapat mengembangkan kegiatan untuk meningkatkan proses kegiatan belajar mengajar ataupun kegiatan lainnya, hal tersebut senada dengan pendapatnya Lickona (1991) sebagaimana berikut:

Character education can interface the learning on each subject. Any subjects related to norms or values in each subject should be developed, dieksplisitkan, associated with the context of everyday life. Learning 
these character values do not stop at the level of cognitive impairment, but touching at the level of internalization, and practice in the life of students in the community everyday

Secara sederhana peneliti mengartikan bahwa pendidikan karakter dapat dilakukan pada setiap mata pelajaran. Setiap mata pelajaran yang berkaitan dengan norma-norma atau nilainilai di setiap Subjek harus dikembangkan, dieksplisitkan, dikaitkan dengan konteks kehidupan sehari-hari. Pendidikan karakter tidak berhenti pada tingkat kognitif, tetapi menyentuh pada tingkat internalisasi, dan praktek siswa dalam kehidupan sehari-hari di masyarakat.

Merujuk pendapat tersebut, maka pendidikan karakter dapat dilakukan melalui cara pembelajaran yang terintegrasi, dalam pengertian bahwa proses pembelajaran adalah pengenalan nilai-nilai, fasilitasi diperolehnya kesadaran akan pentingnya nilai-nilai, dan penginternalisasian nilai-nilai ke dalam tingkah laku peserta didik sehari-hari melalui proses pembelajaran baik yang berlangsung di dalam maupun di luar kelas pada semua mata pelajaran. Dengan demikian, kegiatan pembelajaran selain untuk menjadikan peserta didik menguasai kompetensi (materi) yang ditargetkan, juga dirancang dan dilakukan untuk menjadikan peserta didik mengenal, menyadari, dan menginternalisasi nilainilai dan menjadikannya perilaku.

Kondisi di atas mengindikasikan bahwa peran guru sebagai bagian dari unsur di sekolah, merupakan faktor penting yang besar pengaruhnya terhadap keberhasilan pendidikan karakter di sekolah, bahkan guru sangat menentukan berhasil tidaknya peserta didik dalam mengembangkan pribadinya secara utuh, karena setiap perilaku guru akan berimplikasi dan mempengaruhi nilai serta perilaku siswa, oleh karenanya guru harus menjadi panutan siswa sebagaimana menurut Revell and Arthur (2007 hal. 85 86).Because of the implications for student teachers' attitudes influence the values and behaviour of pupils and that they should be role models to their pupils.

Guru merupakan figur utama, serta contoh dan teladan bagi peserta didik. Oleh karena itu, dalam pendidikan karakter guru harus mulai dari dirinya sendiri agar apa-apa yang dilakukannya dengan baik menjadi baik pula pengaruhnya terhadap peserta didik. Pendidikan sulit menghasilkan siswa yang baik, tanpa dimulai oleh guru-gurunya yang baik.

Dengan demikian pengembangan pendidikan berkarakter bagi siswa harus diterapkan sungguh-sungguh karena kepribadian dan karakter yang kuat mempengaruhi masa depan bangsa karena tidak ada masyarakat yang bisa bertahan hidup jika tidak didorong dengan sengaja perkembangan karakternya pada setiap generasi. Stated that "no society can survive if it does not deliberately foster the development of character in each subsequent generation of youth ( Berkowitz dalam Najah A. R. Ghamrawi, 2012 hal 130).

\section{Simpulan}

Kegiatan guru dalam pembelajaran tidak hanya sekedar mengajarkan nilainilai luhur yang diyakini masyarakat dan bangsa (Moral Knowing), tetapi juga melatih peserta didik untuk mengaplikasikan nilai-nilai luhur tersebut (Moral Training), bahkan perlu membiasakan nilai-nilai luhur dalam kehidupan sekolah dan masyarakat (Moral Behaving), sehingga nilai-nilai yang dijunjung tinggi tersebut menjadi watak peserta didik. Dengan tertanamnya Moral Knowing, Moral Training, serta Moral Behaving pada peserta didik maka akan terbentuk siswa yang berkarakter baik 
dengan melaksanakan nilai-nilai dalam kehidupan sekolah.

\section{Daftar Pustaka}

Agboola, Alex, Kaun Chen Tsai .(2013) Bring Character Education into Classroom University of the Incarnate Word. San Antonio, TX, 78209, USA

Baig, Sharifullah .(2013). Teachers' Perceptions of Their Values, Sources of the Values, and Its Influence on Student Personality Development: A Case Study from Pakistan. Aga Khan University

Djahiri, Kosasih .(1996). Menelusuri Dunia Afektif. Lab. Pengajaran PMP. Bandung

Furkan, Nuril (2012). The Implentation of Character Education through the School Culture in SMA Negeri 1 Dompu and SMA Negeri Kilo Dompu Regency graduate school, Yogyakarta State University.

\section{Ghamrawi,Najah A. R. 1.(2015). Perception of Character Education: The Case of Lebanese School Leaders. Faculty of Education, Lebanese University, Beirut, Lebanon}

Hakam, Kama Abdul .(2013). Pendekatan Pendidikan Karakter di Sekolah Dasar. UPI: Bandung

Pengembangan Model Pembudayaan NilaiMoral dalam Pendidikan Dasar di Indonesia: Studi Kasus di Sekolah Dasar Negeri Bandungrejosari 1 Kota Malang, Jawa Timur

Harms, Kristyn Marie, M.S. (2014). The Impact of Character Education

Curricula on Youth Educators.
Department of Agricultural
Leadership, Education, and
Communication University of
Nebraska

Kesuma, Doni. (2012). Pendidikan Karakter Strategi Mendidik Anak di Zaman Global, Bandung: Rosdakarya .(2008). Pendidikan

Nilai, Value Press: Bandung

Lickona, Thomas (1991), Educating for Character, How Our Schools can Teach Respect and Responsibility, New York, Bantam Books.

.(2004). Character Matters, Bumi Aksara: Jakarta

Mulyana. Rohmat. (2013) Mengartikulasikan Pendidikan Nilai, Rosdakarya: Bandung

Nurihsan, Ahmad Juntika .(2016). Membangun Peradaban Melalui Pendidikan dan Peradaban. Refika Aditama, Bandung

Q-Anees, Bambang dan Hambali, Adang. (2008). Pendidikan Karakter Berbasis Al-Qur'an.Bandung: Simbiosa Rekatama Media.

Syamsuddin Makmun, Abin .(2005). Psikologi Kependidikan. Remaja Rosdakarya: Bandung

Ratna, Nyoman Kutha .(2010). Metodologi Penelitian: Kajian Budaya dan Ilmu Sosial Humaniora Pada Umumnya. Yogyakarta: Pustaka Pelajar

Revell, Lynn and James Arthur (2012). Character education in schools and the education of teachers. 
Canterbury Christ Church

University, UK

Sugiyono. (2016). Metode Penelitian

Kuantitatif Kualitataif dan

Kombinasi (Mixed

Methods).Bandung: Alfabeta. 